\title{
34. RELATIONSHIPS BETWEEN TECTONICS AND SEDIMENTATION AROUND THE NORTHWESTERN IBERIAN MARGIN
}

\author{
Jean-Pierre Réhault, Laboratoire de Géodynamique sous-marine B.P. 48,06230 Villefranche-Sur-Mer \\ and \\ Alain Mauffret, Université Pierre et Marie Curie, Laboratoire de Géologie Dynamique, 4, Place Jussieu, \\ 75230 Paris Cedex 05, France
}

\section{FOREWORD}

In this report, based mainly on sedimentological data from Hole 398D (Leg 47B, drilled south of Vigo Seamount), regional geological information and seismic studies are used to demonstrate the relationship between tectonics and sedimentation on the Iberian continental margin. We also attempt to correlate this information with knowledge of the symmetrical Atlantic margin.

In addition to shipboard results and detailed core descriptions, sedimentological data are based on the examination of 200 thin sections, 300 complementary smear slides, and 1000 coarse fractions (principally, 63 $\mu \mathrm{m}$ sieved residues of micropaleontological samples lent by J. Sigal). Our attention was concentrated on the coarse-fraction material. In the back pocket of this volume, a microfiche packet (Chart 2) contains the sedimentologic elements analyzed in this study. Chart 2, depicting individual constituents of the Cretaceous series, presents analysis of the same samples from Cores 398D-138 to 398D-56 as were studied by Sigal (this volume), and presented in his Chart 1 (also back pocket, this volume). See Appendix A for a user's guide to Chart 1.

The geological aspects considered in this report concern the neighboring areas of Spain and Portugal, and Canada for the beginning of the evolution of the depositional site. Some of these aspects were considered in the Groupe Galice contribution to this volume, especially concerning certain phases of the tectonic evolution; but they are developed in this report from the point of view of tectonic-sedimentary evolution. Seismic profiles used come from "Groupe Galice" cruises (CNEXO, IFP, Paris University) off the Spanish and Portuguese coasts.

\section{INTRODUCTION}

\section{Pre-Cretaceous Tectonic-Sedimentary Evolution of the Northwestern Iberian Margin}

\section{The Earliest Phases of Rifting}

Regional studies of the European and Canadian sides of the Atlantic Ocean strongly suggest that these two margins have undergone two phases of rifting (see Groupe Galice, this volume).
During the Late Triassic-early Liassic phase, basins filled with detrital sediments and evaporites. The nearest example to Site 398 is in the Lusitanian Basin. Another graben seems to be between the Galicia Banks and the continental shelf (Figure 1), where we find diapiric manifestations that suggest deeper Triassic evaporites (Montadert et al., 1974).

A second phase occurred in Late Jurassic and Early Cretaceous time. This was the period of formation of the horsts and grabens that form the structural frame of the Iberian margin. There are about 1500 meters of Upper Jurassic(?)-Lower Cretaceous sediments in the grabens, and 700 to 1000 meters of Aptian-Albian deposits.

\section{The Earliest Known Sediments}

Hole 398D reached Hauterivian sediment, but older strata are known through dredging. Tertiary tectonic events in some regions (such as the Vigo and Porto seamounts) have brought to the surface Uppermost Jurassic-Lowermost Cretaceous strata which elsewhere are buried deeply (Dupeuble et al., 1976, 1977).

Some samples dredged off the escarpment of Vigo Seamount obviously belong to a neritic facies. These include Kimmeridgian-Portlandian bioclastic and algal limestones, deposited in shallow water. This indicates that at the end of the Jurassic period, the region near Site 398 was a continental shelf area. Other samples consist of Kimmeridgian to Berriasian micrites with Calpionellids that suggest a pelagic slope deposit in the open sea. Lastly, the two main facies can be found at the same time in the same sample.

Therefore, it seems that at the Jurassic/Cretaceous boundary, the northwestern Iberian margin had a morphology including epicontinental zones and deeper depressions which were wide enough to allow free exchanges with the Mesogean Ocean, as revealed by the widespread distribution of Calpionellids (Durand-Delga, 1973).

The late history of the Iberian margin is found at Site 398 . We have nearly continuous samples from the Hauterivian and younger strata. This allows us to describe with far more accuracy the tectonic-sedimentary evolution of this margin.

\section{ACOUSTICAL STRATIGRAPHY}

The systematic analysis of $8000 \mathrm{~km}$ of reflection seismic profiles near Galicia Bank, Vigo Seamount, and 


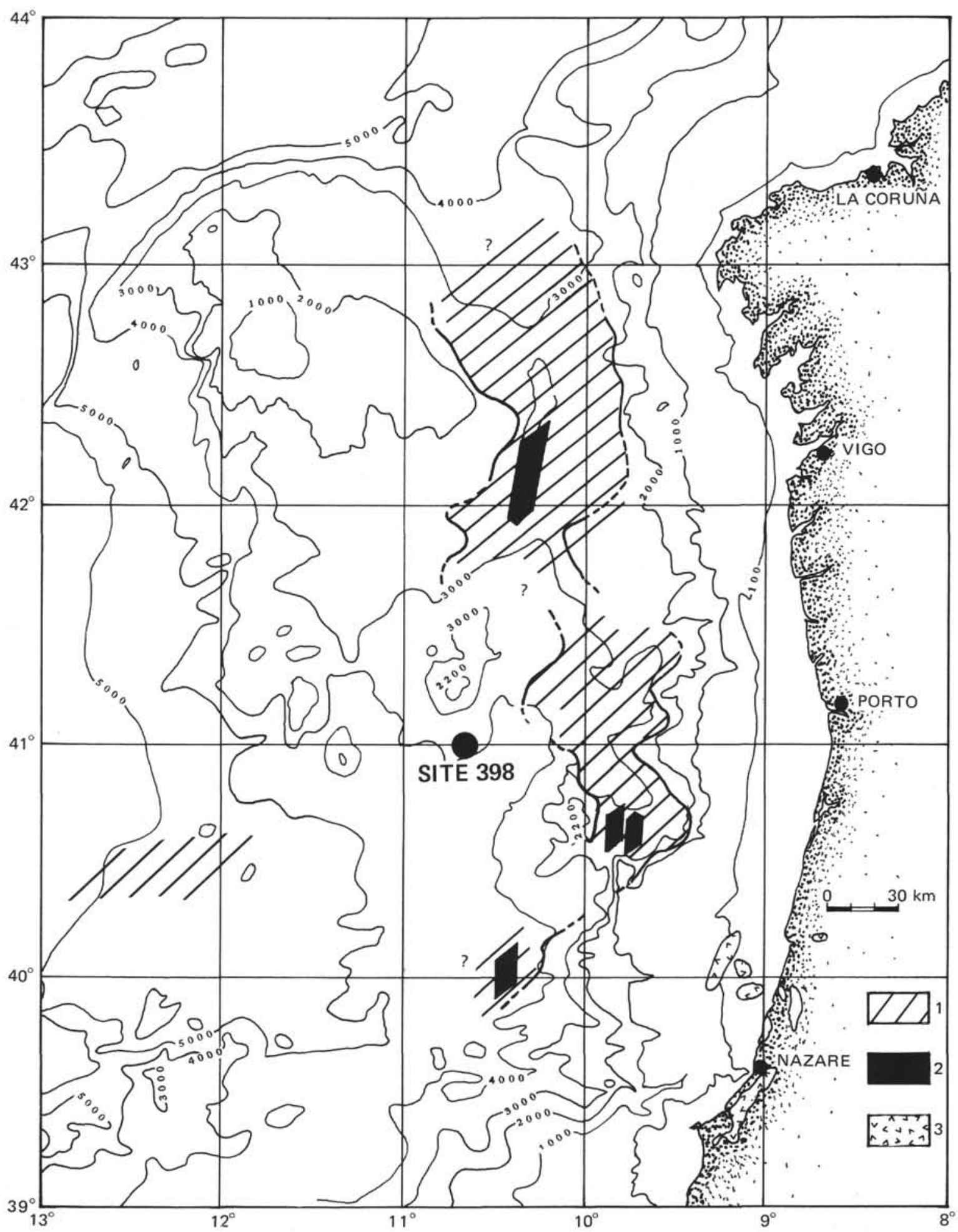

Figure 1. Representation of internal Triassic-Liassic basin (a prolongation of the Lusitanian basin) with diapiric phenomena identified as follows: (1) probable basin extension, (2) diapirs, and (3) known diapirs on land and shelf. Note sliding, south of $42^{\circ} \mathrm{N}$.

Porto Seamount has revealed the superposition of four main sedimentary units. These are characterized by their seismic aspects and their discontinuity, particularly the unconformities (Groupe Galice, this volume).
After the drilling of Site 398, these units have been identified (Figure 2); this enabled correlation between the "acoustic stratigraphy" and the stratigraphic succession (Figure 3). 


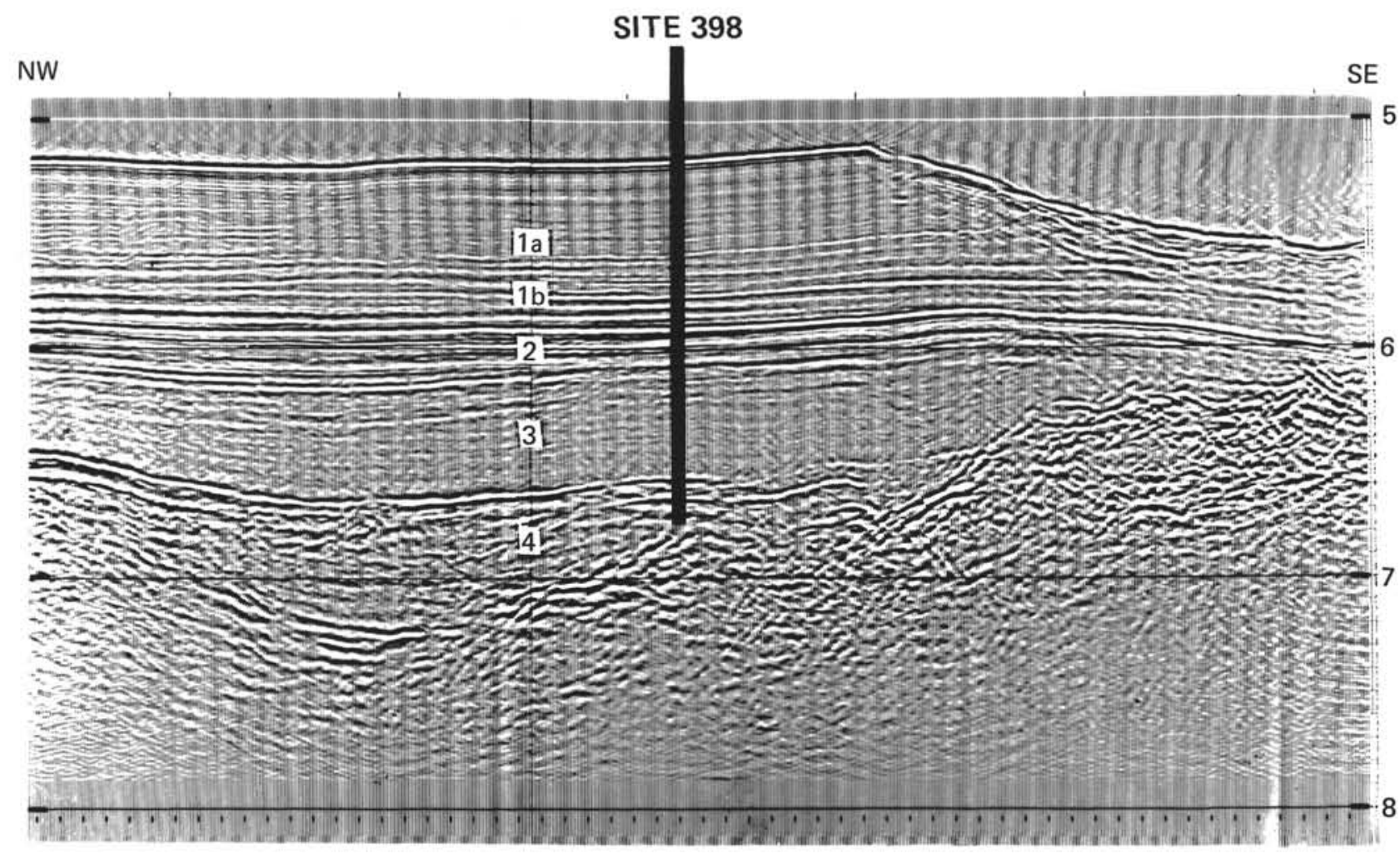

Figure 2. GP-19 profile with positions of seismic units.

Although this report is based mainly on the analysis of sediments, we often refer to the seismic data which complete the analysis and allow us to follow the lateral evolution of the series.

\section{Review of the Principal Sedimentary Units Penetrated at Site 398}

Five units were differentiated based on sedimentological criteria among which the carbonate content had a leading role (Site Report, this volume).

\section{Unit 5 (Hauterivian to Barremian)}

Sedimentary Unit 5 (Cores 138 to 131) consists of pelagic carbonates including an alternation of massive white nannofossil limestones containing radiolarians and laminated marlstones and siltstones deposited above the CCD.

\section{Unit 4 (Barremian to Cenomanian)}

This unit corresponds to the "black shales" in its broadest meaning and is divided into three sub-units see Site Report, and Sigal, both, this volume). We noticed an evolution of the detrital material as to its quantity and composition from the bottom to the top of this unit. The sedimentation rate is lowered with the diminution of the continental contribution.

Sub-unit 4C: At the base the upper Barremian-Aptian series, this sub-unit (Cores 130 to 103) includes graded sequences with turbiditic sandstones and siltstones and numerous slumped beds or debris flows interbedded with dark shales. The coarse clastic influ-

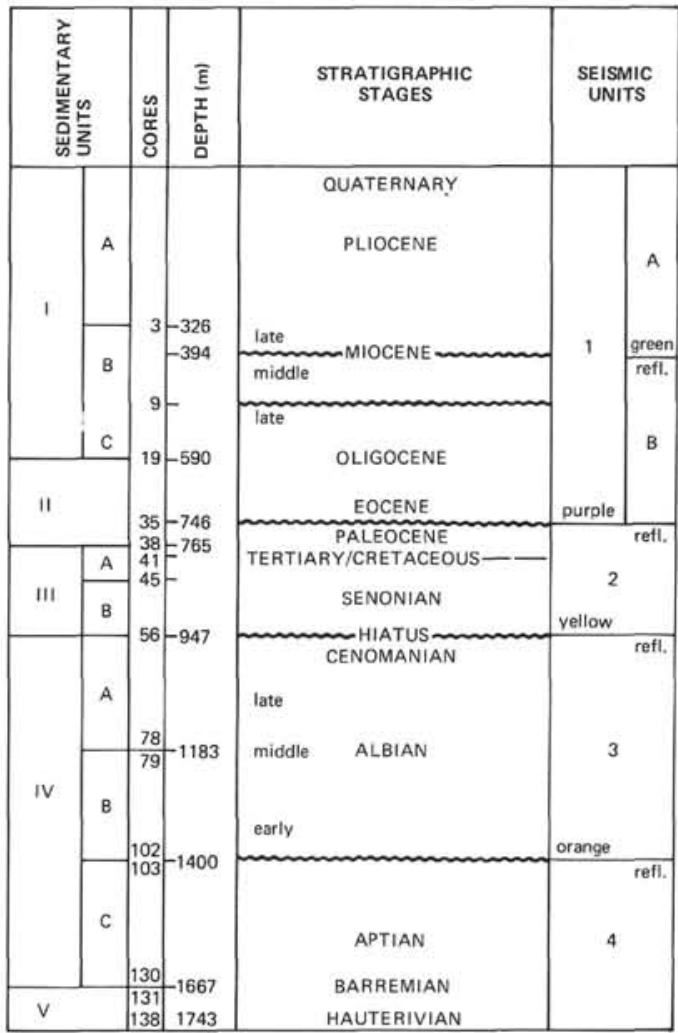

Figure 3. Correlation of sedimentary, stratigraphic, and seismic units at DSDP Hole 398D. 
ence is high and many fault scarp reactivation indications are clear, such as breccias or debris flows containing reworked Calpionellid-bearing limestones.

Sub-unit 4B: The Albian "black shales" or dark claystones (Cores 102 to 79 ) are fine detrital beds with a high content of organic material of continental origin deposited below the CCD. They are interbedded with slightly burrowed and laminated marlstones.

Sub-unit 4A: In the upper Albian to lower Cenomanian series (Cores 78 to 56 ), laminated marlstones and black shales are interbedded with redeposited marls and chalks (Bourbon, this volume).

\section{Unit 3 (Upper Cretaceous and Lower Paleocene)}

This unit (Cores 56 to 39) is separated from the preceding one by the sharpest facies change at Site 398 and a large sedimentary gap. At the base, the series corresponds to red zeolitic claystones deposited below the CCD. Beginning at the Santonian/Campanian boundary, the pelagic carbonate deposits, partly displaced, are suggestive of sedimentation near or above the CCD.

\section{Unit 2 (Paleocene to Lower Oligocene)}

This unit (Cores 38 to 20 ) is represented by a rhythmic turbiditic series of siliceous marly nannofossil chalk and mudstones with slumps, mud, and debris flow beds. It also has a large contribution of fine detrital material. A hiatus is noted in the lower Eocene (Core 32 ), as well as numerous indications of sediment reworking.

\section{Unit 1 (Oligocene to Quaternary)}

The Oligocene series are not very different from the preceding one, with rhythmic turbiditic series of siliceous marly nannofossil chalk and large slumped beds (as in Core 15). The Miocene includes two hiatuses and sedimentation progressively changes to laminated marly nannofossil chalk strongly influenced by bottom current activity. Rhythmic pelagic sequences of foraminiferous nannofossil ooze progressively change to cyclic sedimentation, which still show a significant influence of terrigenous materials and bottom current activity. The cyclical sequence may be the result of climatic and/or eustatic change.

It is not necessary here to describe the strata penatrated; this is done in the Site Report (this volume). Instead, we examine the sedimentological aspects which, we believe, are the consequences of tectonic movements.

\section{EFFECTS OF TENSION TECTONICS DURING THE EARLY CRETACEOUS}

\section{Deepening of Grabens and Normal Fault Movements}

At the bottom of the hole, the deposits show a "deep" sedimentation environment, above the CCD but clearly below the epicontinental source area of turbidites. These deposits could be in continuity with the Kimmeridgian-Berriasian pelagic limestones dredged on Vigo Seamount.

Site 398 was located in a graben. We interpret the sedimentary characteristics of the deposits of Unit 5 as being formed in a "deep" depression surrounded by seamounts that correspond to horsts. Neritic sediments must have been deposited on these seamounts, while in the deep basin and slopes, there was an accumulation of the sediments penetrated by the hole. These deposits include pelagic radiolarian limestones, hemipelagic deposits, and clastic turbidites coming from the seamounts, from the nearby continental shelf (neritic contributions with abundant shell debris such as lamellibranches, gastropods, aptychus inoceramus), and even from the adjacent continent (vegetal debris, angular quartz, micas, clay minerals [Chamley et al., this volume], etc.). Some of these sedimentary facies are shown in photographs of thin sections (Plate 1, Figures 1, 2, and 3). These rhythmical deposits are representative of base of slope or continental rise sedimentary environments. They infill the depressions.

This irregular bathymetric setting, determined by a horst and graben structure, persisted throughout the Early Cretaceous. Different clues suggest that the formation of the grabens was prominent during the Barremian and early Aptian (the base of Unit 4). These clues (from Core 130 upward) are as follows:

1) A rhythmic sedimentation with graded sequences.

2) Intercalation of thick and coarse-grained turbidites and numerous slumped beds and debris flows, as in Cores $129,128,125,124,121,117$ to $115,113,112$, and 106 to 103 .

3) Breccias of sub-rounded pelagic limestone pebbles with internal flow structures.

4) The presence of Tithonian Calpionellids in white limestone clasts, as in Cores 125, 124, 116, 112, 106, and 105 (Plate 1, Figure 5).

5) Abundant coarse continental debris including vegetal matter, quartz, micas, and feldspar, as illustrated by Plate 1, Figures 4 and 6 and in Plate 2, Figure 1; but also a high content of clay minerals, especially illite and kaolinite (Chamley et al., this volume).

6) A strong increase in the sedimentation rate.

7) Deposition below the CCD, through Cores 128 to 120 (see Sigal, this volume).

The rhythmic and turbiditic sedimentation predominates throughout sedimentary Sub-unit $4 C$ and is linked to a subsiding sea floor within a complex horst and graben system. Slopes are intensively reactivated by synsedimentary tensional tectonic events, as indicated by the reworking of Tithonian Calpionellid pebwacke layers with redeposited metamorphic rock fragments, as in Sections 118-2, 117-4, 104-1 (see Bourbon, this volume), shows the intensity of tectonic reactivations that affected the Upper Jurassic sediment cover as well as the underlying basement. 
These tensional tectonical manifestations are related to a late phase of the second rifting and may be a prelude to the beginning of sea-floor spreading.

A careful analysis of the top of seismic Unit 4 (Figure 2) reflects this sedimentary phase of rhythmic and turbiditic deposits which are more or less irregular and present light internal discordances. In the upper Aptian, there is a massive turbidite and slumped bed, coarse and carbonate-rich, which is responsible for the discontinuity between seismic Units 4 and 3. This corresponds with the Clansayesian gap (Sigal, this volume). The upper surface of this unit is clearly depressed (GP-19) and is affected by significant deformation ( $>700 \mathrm{~m}$ on Vigo Seamount area). A chart of the distribution of formation 4 is presented clearly showing its position in the old depressed areas (Figure 4). Seismic Unit 4 does not exist on the true oceanic crust and its extension is correlated with the boundary of Mercanton Zone defined in the Groupe Galice contribution (this volume).

In summary, the tectonic depressions, already clearly defined in the bathymetry and sedimentology of the basal Cretaceous, were sharply deepened in the lower Aptian (Bedoulian). This prepared the setting for the "black shale" sensu stricto.

\section{The Filling of Grabens and Deposits of Black Shales Sensu Stricto}

After the early Aptian, the basin still received turbidites and the autochthonous sediment consisted of fine material with low amounts of carbonate.

From Core 102, the most typical lithology term is represented by massive black claystones without carbonate and with common plant fragments and fish remains.

Frequently, there are intervals where the same detrital claystones are finely interbedded with many parallel laminae of marlstones and, in some instances, with thin silt beds. The conclusion is that the autochthonous sedimentation is a residual argillaceous product deposited below the CCD (Plate 2, Figure 2) with a clear terrigenous impact more or less diluted by minor, distal turbidite contributions including carbonates (see Sigal, this volume).

Radiolarians are ubiquitous, often very diversified and generally uncalcitized. Also, we commonly find fish remains, spicules, and plant debris. Coarse quartz grains $(>63 \mu \mathrm{m})$ are very rare except in the laminites, but are present as very fine grains. Micas are far more numerous and often are mixed with vegetal fragments, sometimes coalified or pyritized, very well preserved, and ranging from 5 to $>7$ per cent of these deposits. They are responsible for the black color of the shales. Pyrite is plentiful and always present, and indicates reducing environmental conditions.

The almost total dominance of the detrital components clearly indicates the continental origin and explains the very high sedimentation rate for these Albian sediments.

The presence of minerals such as pyrite (found on plant debris, radiolarians, or in microspherules) and as siderite (recrystallized radiolarians and recrystallized laminated levels) shows the diagenesis in the black shales and underlines the reducing conditions. Barite and gypsum also were noted frequently. Gypsum appears as fine crystals, often twinned in the washed remains. Gypsum is generally scattered in the sediment but numerous laminations are gypsum-rich. If one considers gypsum as being neoformed, one must retain the possibility of detrital gypsum coming from the nearby Triassic-Liassic salt domes, as in Core 82 where gypsum is far more abundant and where there are also exceptionally large amounts of shell debris and spicules. On the IFP OC-103 profile (Figure 5), it is obvious that salt structures affect the entire thickness of Unit 3. A large fragment of barite in Core 69 could have been derived from such a structure. This phenomenon also occurs at Site 369, DSDP Leg 41 (Lancelot, Siebold, et al., 1975). At Site 369, Aptian-Albian black shales and silty marls contain barite rosettes possibly resulting from the upward or lateral (or both migration of solutions from Jurassic evaporites underlying the continental shelf and slope). It is logical that the salt domes should evolve during this period of tensional tectonics.

The sedimentological observations, combined with analysis of the seismic profiles, strongly indicate that the grabens no longer offset sedimentation after the Aptian. Not only do the Albian black shales fill the grabens but they often cover surrounding areas. Everywhere they are transgressive but the unconformity on the Aptian black shales is not obvious. We interpret this geometry as signifying that rifting had stopped during the Aptian and that the Albian vertical movements were only an isostatic response of the margin by regional cooling. The very high sedimentation rate observed during that period is the clearest consequence of the beginning of this regional subsidence.

During the late Albian and early Cenomanian the graben-filling ceased, the sedimentation rate decreased, and the first condensed series appeared, proof of the beginning of oceanic spreading. The sediments at this time gain calcareous components of turbiditic origins. Bottom currents are evident and develop laminations. There is a strong decrease in detritus of continental origin. This detritus is diluted by calcareous-displaced sediments from more proximal sources such as underwater slopes. Early and middle(?) Cenomanian strata are very thin and result from condensed sedimentation (see radiolarites layers) as well as reworked material.

\section{EFFECTS OF GENERAL SUBSIDENCE OF THE MARGIN AND OPENING OF THE ATLANTIC}

The Upper Cretaceous layers are thin, but cover the entire continental margin. We cannot notice any variations in thickness over the active horsts and grabens at the Early Cretaceous (Figure 6). The basal unit is defined by a very sharp seismic discontinuity (the limit between the seismic Units 2 and 3). This developed through a sharp change of facies and an obvious lack of erosion on the slightly deformed black shales on the sides of the drill site. 


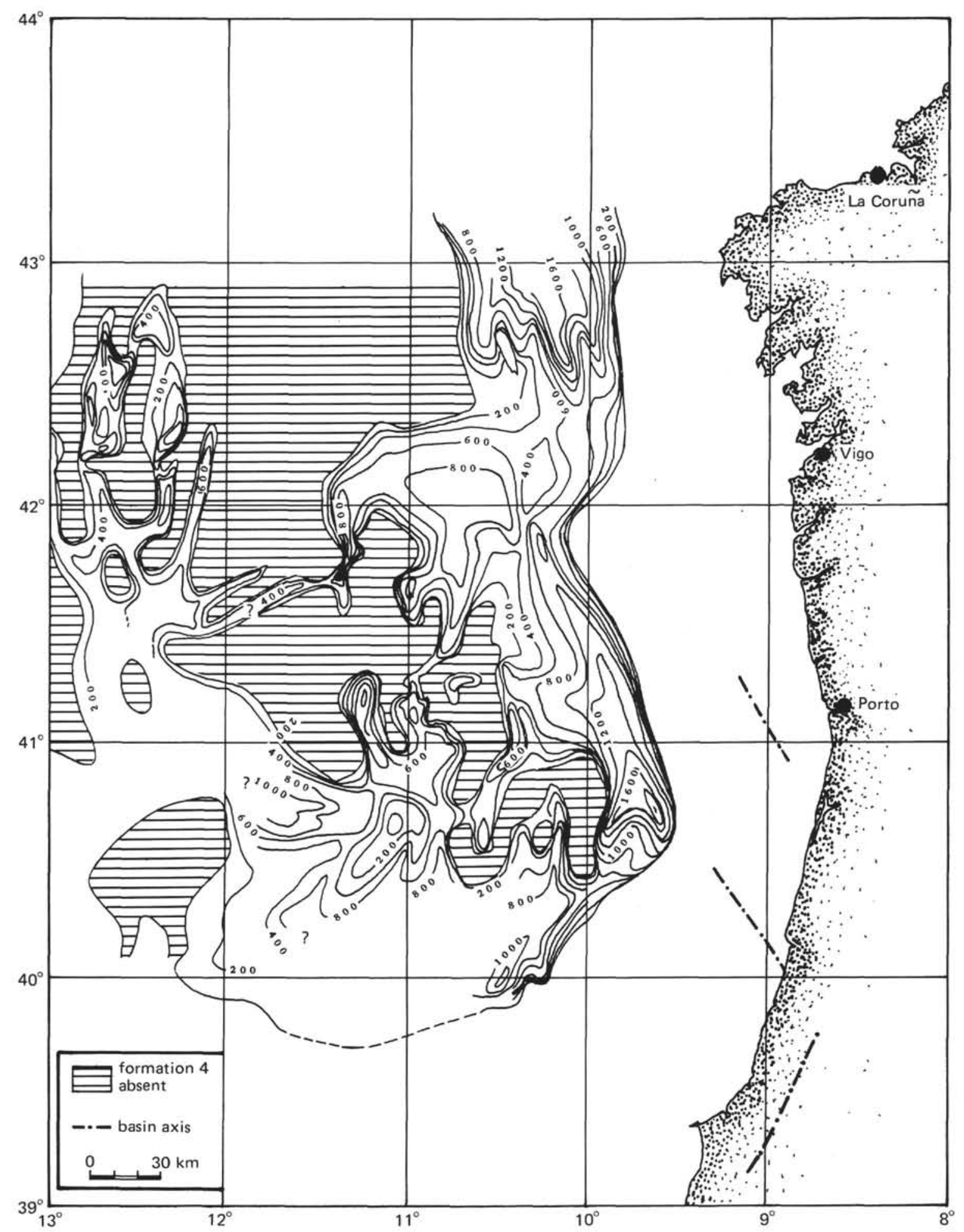

Figure 4. Isopach chart of seismic Unit 4 (pre-Albian series). This unit was deposited in the depressions made during the two rifting episodes (Triassic-Liassic and latest Jurassic-Early Cretaceous). Note the sedimentary series of the "internal basin" as well as the north-south basins to the west of the Galicia Bank. The Galicia, Porto, and Vigo banks must have been emergent at that time because of their relatively thin sediment cover. 


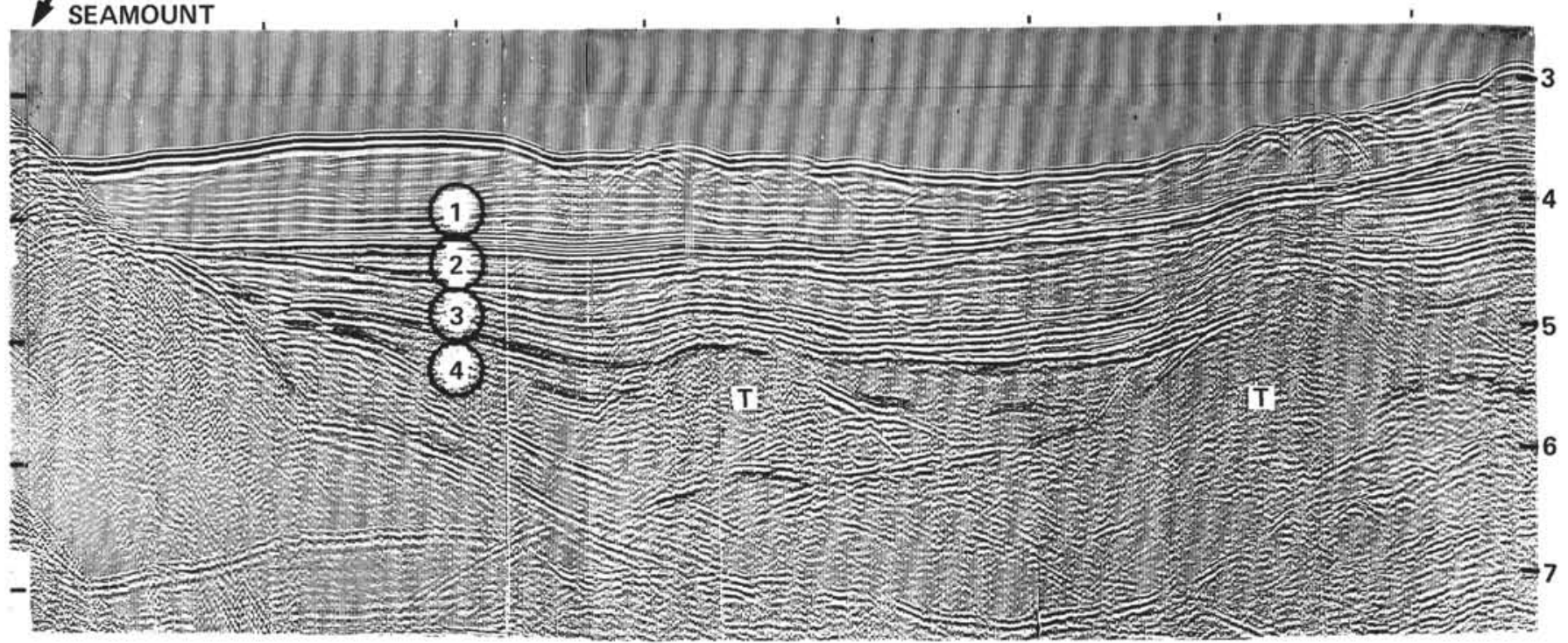

Figure 5. Profile OC-103 (Montadert et al., 1974), between Porto Seamount and the Iberian margin, depicting the entire sedimentary history of the region. Within seismic Formation 4 we recognize the diapiric structures (T) of Triassic-Liassic age. At the base, we recognize a layered series which seems to merge with the diapirs and could form their basal layer. The diapirs affect Series 3 ("black shales") and, partly, Series 2. Note the dual nature of seismic Facies 3 which is layered at its base and is transparent in its upper part. This series, like Formation 4, has a transgressive shape and a regular inclination from the Porto Seamount, suggesting the antiquity of this structure. A marked discordance limits Formations 2 and 3. This can be correlated with the Cenomanian discordance. Formation 2 also has a marked transgressive aspect. Series 1 is equally discordant over Series 2. The sea bottom exhibits erosive and depositional features due to deep currents.

At the level of Sample 398D-56-2, $19 \mathrm{~cm}$, the sharpest facies change in the entire section occurs (Figure 7).

The black shales are succeeded by red zeolite claystones which are carbonate-free and without any biostratigraphical significance, at least up to Core 50, which marks the Santonian/Campanian boundary (see Maldonado, this volume). There is also a noticeable change in the NRM intensity that becomes very high (see Morgan, this volume).

This new stage of sedimentation on the Iberian margin is a consequence of the spreading in the Atlantic Ocean (Hays and Pitman, 1973; Hart, 1975). This opening led to the initiation of the deep oceanic circulation, the oxidation of the sediments, and the local formation of condensed series or sedimentary hiatuses. At the same time, the large Cenomanian transgression over the continent took place. This results in the decrease of the amount of terrigenous matter in the sediments related to the removal of the source areas, e.g., the Portuguese shelf, became submerged (Mougenot, 1976; Lamboy, 1976; Muselec, 1974). Conversely, we note an increase in the amount of organic material (see Deroo, et al., this volume). The general subsidence of the continental margin ceased, and the area of Vigo seamount then assumed a position which can be compared to its present one, at the foot of the slope. The sedimentation has a character of continental rise type.

\section{EFFECTS OF TECTONIC MOVEMENTS AT THE END OF THE CRETACEOUS AND TERTIARY PERIODS}

Local studies (Groupe Galice, this volume) have shown that the northern margin of spain and its western prolongation into the region of the Galicia Bank had suffered several phases of deformation:

a) During Paleocene to Eocene time (Galicia Bank, Spanish north margin) (Sibuet and Le Pichon, 1971; Boillot and Capdevilla, 1977; Boillot et al., in press). gin).

b) During the late Oligocene (Spanish north mar-

c) In the middle Neogene (west Iberian margin); the region of Galicia Bank, Spanish north margin.

The stratigraphy of Site 398 must be compared to this chronology of tectonic phases defined from other data.

\section{Effects of Late Cretaceous to Eocene Tectonic Movements}

From late Barremian time, the sea floor of Site 398 has been situated below the CCD. Beginning at the Santonian/Campanian boundary (Core 50), the sediments of the Late Cretaceous and the Eocene have some calcareous pelagic components, which indicate that the depositional site was again located near or 


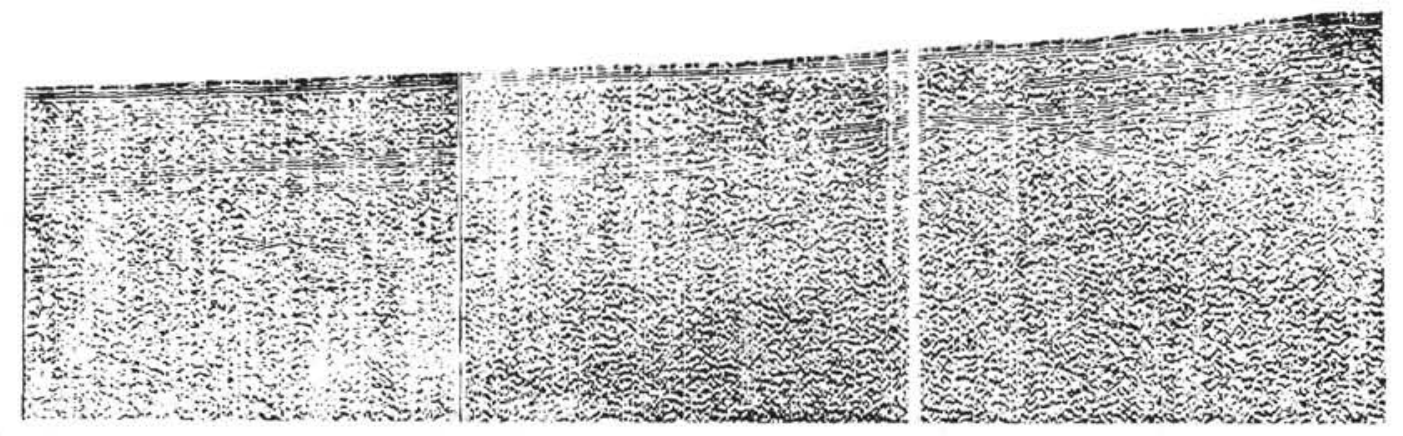

SW

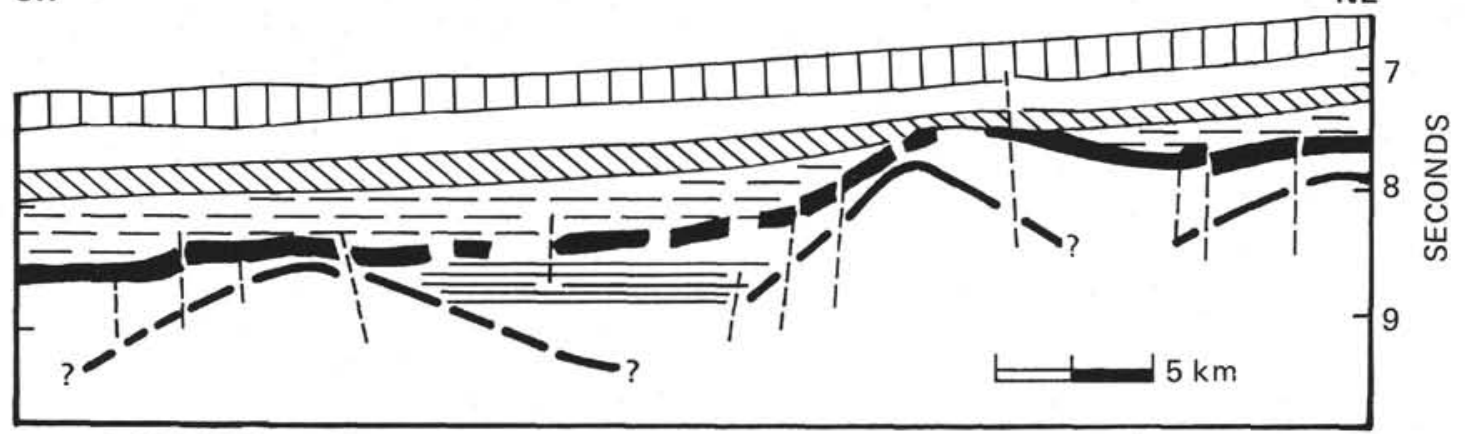

ACOUSTIC UNITS

TRIPODE 16

vertical exaggeration $\times 5$

$\prod \prod$ Unit 1a

guide layer

Unit $1 b$

Unit 4

MVUnit 2

$\longrightarrow$ acoustic basement

E- Unit 3

Figure 6. The discordance and transgressive aspects of Series 2 on a topography subdued by black shale deposits are shown here. Pre-existing structures have not affected the deposits of Series 2.

above the CCD (Plate 2, Figure 3). This was a local event; nowhere else in the Atlantic Ocean did such a change occur and we exclude a general lowering of the CCD, linked, for example, to a climatic phenomenon. Thus, we interpret the return of carbonate sedimentation as being due to a regional uplift linked to a compressive tectonic episode in latest Cretaceous to Eocene time along the Spanish north margin and the Pyrenees (Sibuet and Le Pichon, 1971; Boillot and Mougenot, 1977; Boillot and Capdevilla, 1977). But on the continental margin, the depth of the CCD is variable with local influences as upwelling or others (Lancelot, oral communications).

The following items also substantiate this tectonic episode:

a) The pelagic settling of sediments is marked in Paleocene time, by abundant reworking as in Cores 40 , 39 , and 38 (Plate 2, Figures 4 through 6). b) Micro-faults and slumps occur at the base of the Paleocene (Cores 37 and 36).

c) At the Paleocene/Eocene boundary (Cores 35 and 34), there are interbeds of debris flows which indicate the reactivation of relief.

d) A sedimentary hiatus (see Iaccarino, this volume) is noted in Core 32 which correlates with the discontinuity between seismic Units 2 and 1B.

e) Throughout the Paleocene and the Eocene, the sediments are enriched with sandy, silty detrital elements in the form of coarse-grained turbidites.

f) Some Eocene intervals include slump zones (Cores 29 and 28), reworked Maestrichtian fragments (Core 27), and neritic deposits (Nummulite and bryozoan, Core 26).

From Core 22, situated at the Eocene/Oligocene boundary, the remains of dissolution on the calcareous tests again suggest a depth near the CCD. A possible 


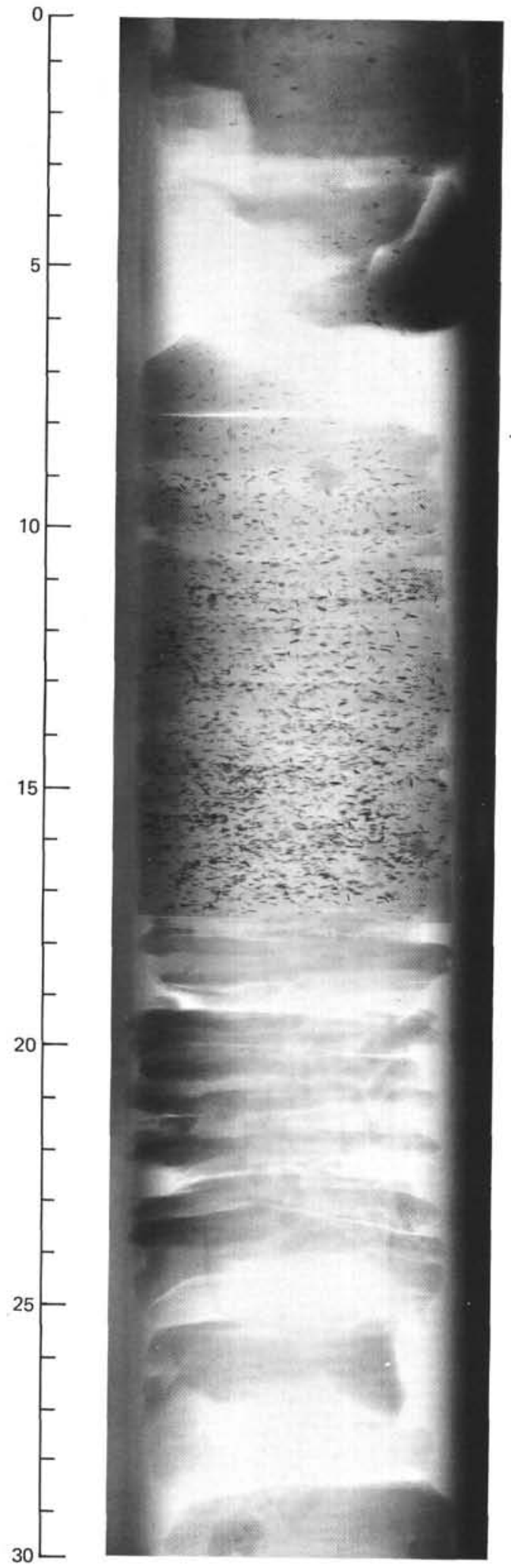

Figure 7. X-ray analysis of Section 56-2 containing the Cenomanian unconformity. The break is underlined by an $18-\mathrm{cm}$ bed of debris. Above the red claystones are finely lithified resedimented strata with an apparent grading at $10 \mathrm{~cm}$. Below the break are dark claystones and radiolarites $(26-28 \mathrm{~cm})$. sedimentary hiatus is also suggested. This deepening may correspond to the transgression at the end of the Eocene which followed Pyrenean tectonic movements on the northern margin of Spain. Additionally, Eocene reverse faults were recorded north of Galicia Bank (see Groupe Galice, this volume). These movements are well illustrated on Figure 8.

\section{Effects of Late Oligocene Tectonic Movements}

On the seismic profiles, there is a slight but persistent discordance between the Oligocene (seismic Formation 1B) and Miocene (seismic Formation 1A). This discontinuity is marked in the sediments by important slump intervals, as in Core 15 which suggests an increase in continental relief (Figure 9) at that time.

Apart from these signs of undersea slumps, we do not find a major change in sedimentation. Homogeneous, carbonate-rich sediments were formed by turbidites and contourites from the Eocene to the late Oligocene and during the entire Miocene. Those were deposited slightly above the CCD and with a relatively important admixture of fine-grained detrital sediments.

A change in the current regimen was noted in lower Oligocene strata and evidence of bottom current activity is strong in Miocene deposits.

\section{Effects of Neogene Tectonic Movements}

Although clearly shown by the seismic records (Groupe Galice, this volume), the effects of Neogene tectonic movements do not appear in the sedimentary column. The general evolution of sedimentation during the Neogene is marked only by a progressive diminution in detrital input and by a slight fluctuation in the rhythmicity of the turbidites and contourites. This relative continuity of sedimentation (which elsewhere is often disturbed in the Neogene) may be a consequence of the drill site being located in a region sheltered by Vigo Seamount.

Site 398 is located on the west side of a low sedimentary rise. A channel persists to the east between Vigo and Porto seamounts. This channel is a conduit for the main flow of continentally derived sediment in this area and establishes a communication with the Iberian Abyssal Plain. The phenomenon is increased by a flexure to the south; we can observe the strata clearly thicken in that direction (Figure 10).

\section{CONCLUSIONS AND GENERALIZATIONS: A COMPARISON WITH OTHER ATLANTIC AREAS}

\section{The First Tensional Phases}

Triassic-Liassic tensional effects are very noticeable in the central Atlantic and extend to the North Sea. One can presume that the Grand Banks separated from the Galicia Bank at that time. One can also speculate that the graben that separated Flemish Cap from Galicia Bank was not larger than the internal basin of GaliciaPortugal, and it is doubtful that an oceanic crust was created. Possibly, however, an intermediate crust exists under the evaporites. 


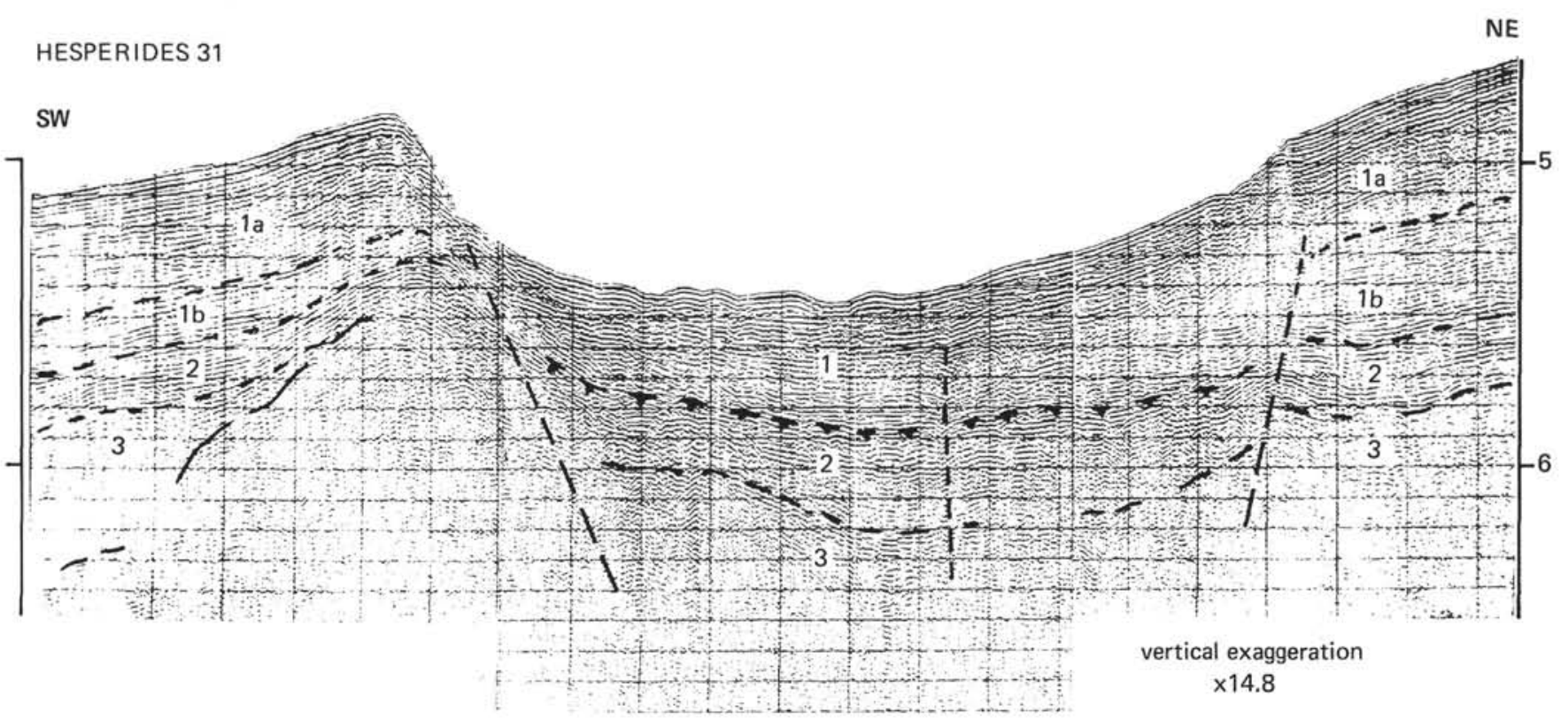

Figure 8. Profile depicts folding and faulting of Horizon 2, as well as the difference in thickness of Series 2 between depositional highs and lows. This profile illustrates the reactivation of older fractures during the Eocene.

As on the European margin, we note on the American side a large area of Triassic-Liassic saliferous series in the Gulf of Maine, Georges Bank (Ballard and Uchupi, 1972; Jansa and Wade, 1975; van Houten, 1977), and especially in New Foundland, an area opposite to Galicia Bank in all plate reconstructions. One can notice an obvious analogy between the western ridges of the Galicia Bank margin (Figure 11) and those existing in the Sed- imentary Ridge Province where they have been interpreted as being salt walls (although their link with volcanism and fracturation has been equally underlined by Jansa and Wade, 1975).

In Portugal, after the deposition of evaporites, a large transgression took place during Middle Jurassic and persisted until the Callovian. Probably an open sea area existed in the area of Galicia Bank (Mougenot, 1976),

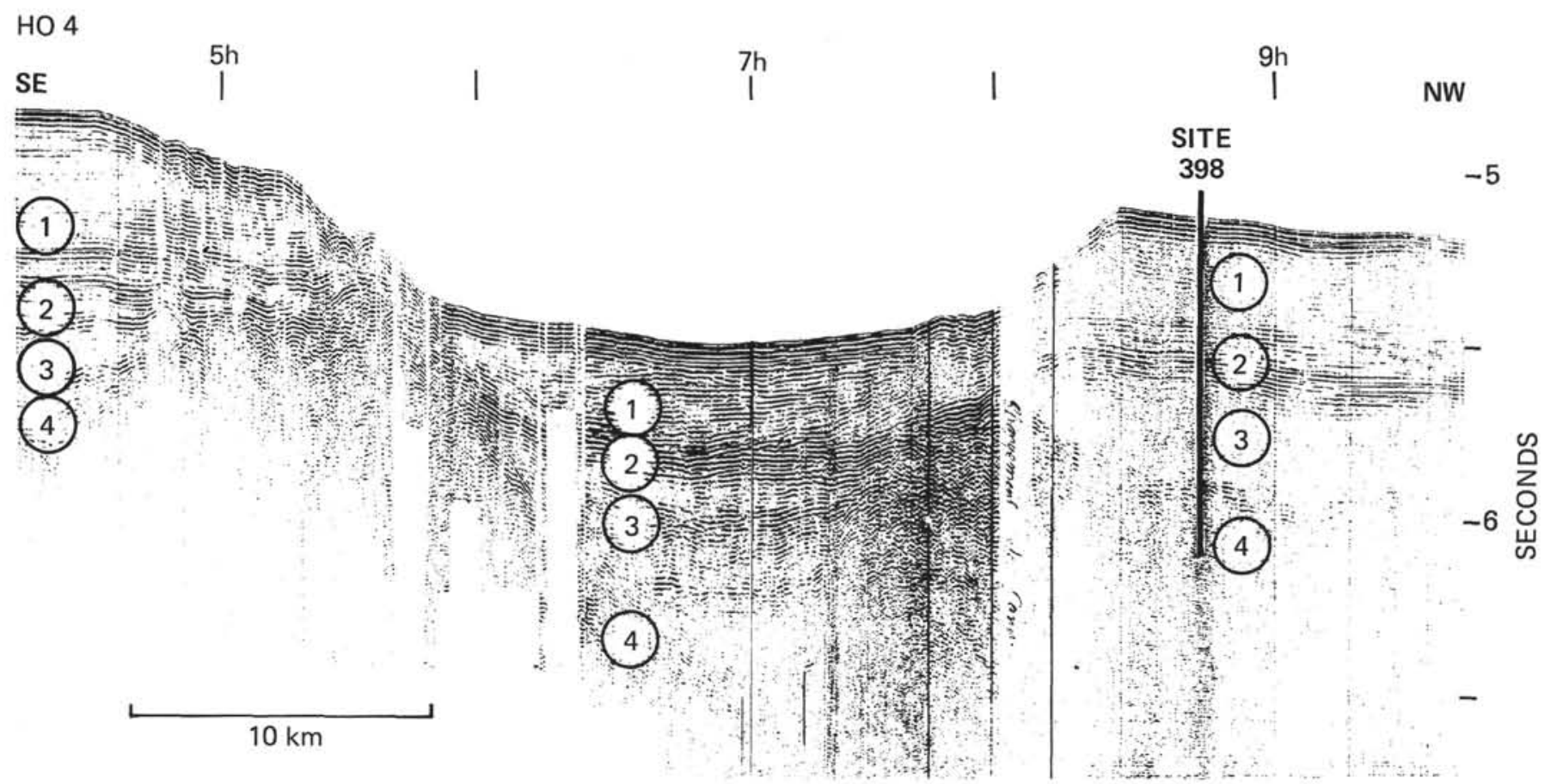

Figure 9. Profile between Site 398 and land. Note the basin which has isolated the drill site. Series 1 is thicker on the continental margin, whereas Series 2 and 3 are thicker at the drill site. Isolation of the site occurred after Series 2. Notice the action of the currents, which is obvious in the channel (discordance between 1 and 2). 


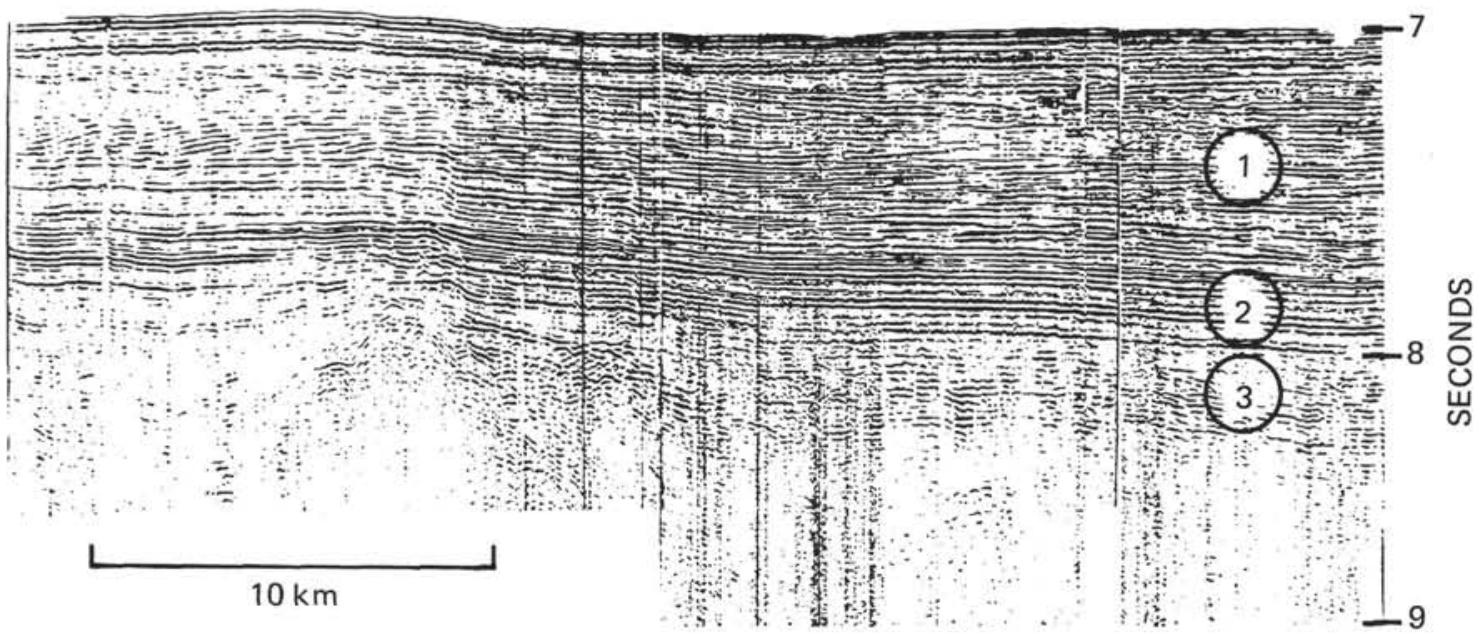

IBERIAN ABYSSAL PLAIN

Figure 10. Profile of the Iberian Abyssal Plain showing the thickening of Series 1 towards the south. This phenomenon is due to differentiated subsidence between the North and South from the Eocene time because of the flexion of the Abyssal Plain. The Galician Bank has formed a barrier against the sediments from the North Coast. On the contrary, in the South, the flow of sediments is direct. Note the sedimentary phenomena caused by the deep currents and prograding at the basis of Series 1.

but without important drifting between Grand Bank and Galicia Bank because the transitional zone is bordered by the Cretaceous quiet zone (Mercanton zone) in the Iberian Abyssal Plain (Hayes and Rabinowitz, 1975; Groupe Galice, this volume). On the Canadian side, a regression (argillaceous sandstones of Mohawk formation) took place. A transgression followed, beginning during Callovian-Oxfordian time and finishing at Kimmeridgian time. On Orphan Knoll, DSDP Site 111 has
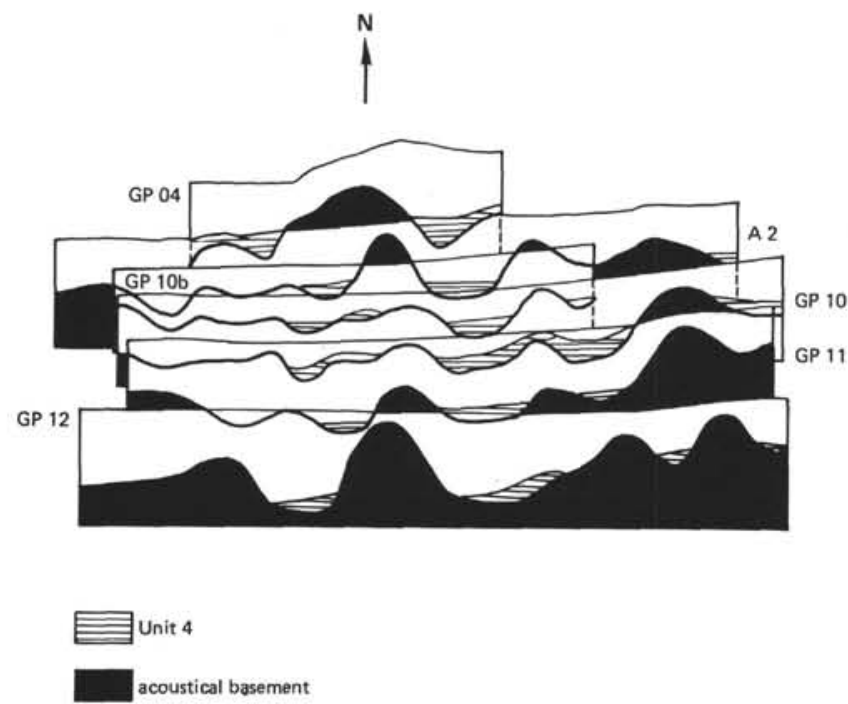

Figure 11. North-south lines of acoustic basement in the transitional zone at the foot of the Galician shelf. Seismic Unit 4, the pre-Albian sedimentary series, fills the depression bottoms. Examination of the seismic profiles suggests these structures are either diapiric manifestations or volcanic features. revealed continental Bajocian formations (Laughton, Berggren, et al., 1972).

The second rifting (Late Jurassic-Early Cretaceous) is difficult to date with precision because this episode encompasses a large period. Nevertheless, the Late Jurassic regression started in Callovian time in Portugal and may be linked to thermal doming which precedes and accompanies rifting.

It is during the second rifting phase that the clear separation of Europe from American must have taken place. One can notice the resemblance to the Canadian Margin in that Calpionellids have been found in the farther offshore areas, while algal facies occur near the coast (Jansa and Wade, 1975).

In Portugal, the Kimmeridgian-Portlandian is represented by calcareous sandstones which indicate the beginning of the subsidence in local grabens (Mougenot, 1976). On Leg 11, white and gray Tithonian-Neocomian limestones (Sites 101 and 105) (Lancelot et al., 1972) or non-lithified carbonate oozes and chalk, without compaction (Sites 99 and 100) were recovered. These series contain slumped beds in the lower part which correlate with tectonic movements at that time. The series is interpreted as being deposited in a deep bathyal environment (Lancelot et al., 1972).

Accordingly, during Leg 44 at Site 391 (Bahama Basin; Benson, Sheridan, et al., 1976), calcareous strata from lower Tithonian to Barremian (gray and white limestones, somewhat clayed) were cored. Similarly at Site 367 (Leg 41), red argillaceous KimmeridgianPortlandian limestones were drilled on basalt and the calcareous series encompassed Tithonian to Barremian sediments (white and dark gray limestones). In conclusion, it is possible that the Tithonian that was not reached at Site 398 may precede the Hauterivian basal carbonatic 
series and should correspond to the dredged pelagic Tithonian facies (Dupeuble et al., 1976).

The Late Jurassic-Early Cretaceous rifting phase is equally visible on the Canadian margin and is expressed by tectonism in horsts and grabens (Avallon Uplift) that spreads from Upper Jurassic to the Neocomian. It is linked to the breakup of Europe and America (Grand Bank-Galicia Bank separation; Jansa and Wade, 1975).

The extent of turbidite deposition and the numerous signs of synsedimentary fault scarp reactivations are linked at Site 398 with a large influx of continental sediments. In Portugal, the Early Cretaceous is represented by fluvial detrital sediment derived from an eroded terrain (Rey, 1972; Mougenot, 1976). This is in accordance with the increasing importance of the continental elements that have been observed there. In Canada, one similarly notes coarse detrital series such as the Messisauga formation (Jansa and Wade, 1975). The tensional tectonics is strongly marked until the late Aptian at Site 398. The youngest large, thick turbidites are certainly linked to the end of the rifting movement. The upper surface of seismic Unit 4 is clearly depressed and the discontinuity there is linked to the Clansayesian hiatus.

\section{Subsequent Tensional Movements}

The Albian black shales are still infilling depressions (Figure 12). This in an actively subsiding environment related to the isostatic response of the margin to sedimentation. The high sedimentation rate is linked to this strong general subsidence which resulted in thick continental detrital series. In Portugal, the regression became more marked in the late Aptian stage and is now entirely emergent (Rey, 1969). In Canada, the "Eider Formation" is marked by conglomerates and unconsolidated sands with coal, siderite, and pyrite (Jansa and Wade, 1975).

In the Atlantic Ocean, black shales are found again at the American Margin (Leg 11, Lancelot et al., 1972), in the Bay of Biscay (Leg 48, Montadert, Roberts, et al., 1976), and in the Bahama Basin (Leg 44, Benson, Sheridan, et al., 1976). They are also known in the older Tethys (Bernoulli, 1972).

Linking to the deepening of the North Atlantic and South Atlantic oceans resulted in a major regression accompanied by considerable continental erosion. The climatic conditions favored an almost complete absence of vegetation on the emergent lands.

\section{General Subsidence and The Opening of the Atlantic}

The Cenomanian transgression is registered in Site 398 as the sharpest facies change. This is linked to a large erosional hiatus obvious on all seismic records, traversing surrounding areas. We also note a major change of NRM, redox conditions, condensed sedimentation, and the spreading of sediments by oceanic currents.

The large hiatus from middle Cenomanian to early Senonian is related a worldwide event recognized in

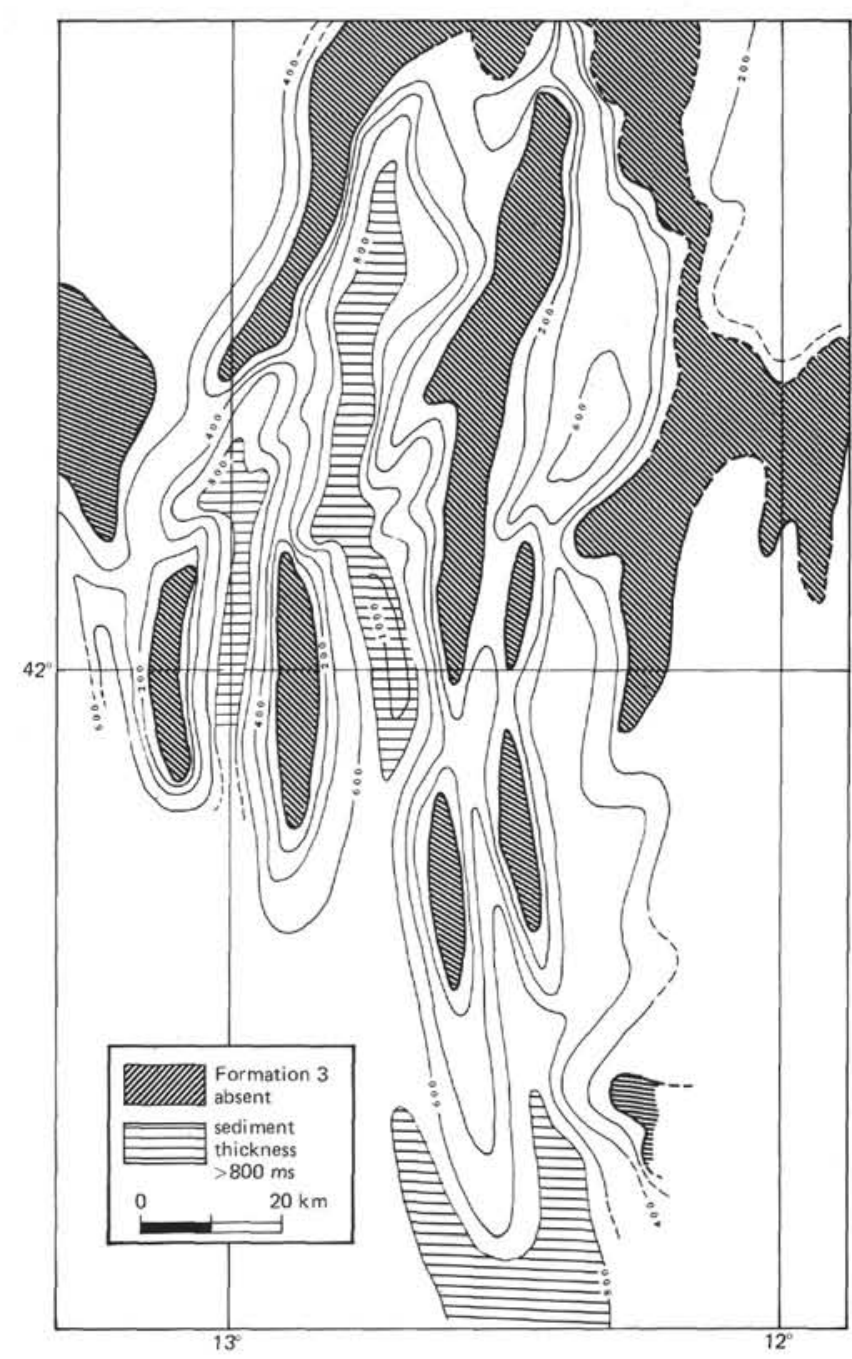

Figure 12. Distribution of seismic Formation 3 corresponding to the "black shales" or equivalent formations. It fills the depressions at the foot of the Galician Shelf.

the North Atlantic and surrounding areas (Bartlett and Smith, 1971; Hart and Tarling, 1974; Hart, 1975). This event corresponds to the important rifting phase in the Atlantic (Wilson, 1975; Laughton, Berggren, et al., 1972). It was accompanied by subsidence of the continental margin previously eroded and correlates with a large transgression on land. During this period of active spreading, the Mid-Atlantic Ridge also increased considerably in volume (Hays and Pitman, 1973).

The presence of oxidized sediments indicates the establishment of a deep oceanic circulation. Dissolution of carbonate is more a regime of cold bottom currents. A similar phenomenon, though more recent, was noticed by Leclaire (1974) in the Indian Ocean; he interprets sediment gaps there in accordance with climate changes and glaciations.

The Upper Cretaceous hiatus is frequently observed in the Atlantic Ocean. Therefore, at Sites 390 and 392 (Leg 44, Benson, Sheridan, et al., 1976), the Campanian lies directly on the Albian. At Site 386 (Leg 43, 
Tucholke, Vogt, et al., 1975), one observes upper Cenomanian to upper Maestrichtian varicolored claystones on Albian to lower Cenomanian black claystones.

\section{The Cenozoic Compressional Movements}

Compressional movements observed in the Galicia Bank area are correlated with orogenic phases of the Pyrenees and of Betic and Rif Belts. They could not be defined in the Atlantic Ocean where only large-scale climatic events were noted (Iaccarino, this volume).

We have not identified a significant correlation with Horizon A; nevertheless, a slight increase of silica linked with detrital and dissolution effects in the Eocene were noted.

The compressional movements of the Late Cretaceous-Eocene phase are linked to the subduction of oceanic crust north of the Iberian plate. The Oligocene and Miocene were affected by the compressive alpine tectonics, particularly active in the southern Iberian Peninsula and in northern Africa.

In summary, the Mesozoic tensional movements were clearly registered in the sedimentary series as the Cenomanian transgression, more clearly than the $\mathrm{Ce}$ nozoic stresses. The northwestern Iberian margin has not been a typical passive margin since Tertiary time.

\section{ACKNOWLEDGMENTS}

We thank DSDP and IPOD-France for participation in Leg 47B and post-cruise studies. We are especially grateful to J. Sigal who has shared his vast experience with us. We also had fruitful discussions with S. Iaccarino, A. Maldonado, J. L. Auxiètre, G. Boillot, M. Bourbon, J. P. Dunand, O. de Charpal, and P. C. de Graciansky.

Special thanks to J. L. Auxiètre and J. P. Dunand for their drafting help and for all our colleagues of Laboratoire de Géologie Dynamique in Paris and Villefranche. Our thanks are also due to $\mathrm{Y}$. Lancelot for reviewing this text.

\section{REFERENCES}

Ballard, R. D. and Uchupi, E., 1972. Carboniferous and Triassic rifting: a preliminary outline of the tectonic history of the Gulf of Maine, Geol. Soc. Am. Bull., v. 83, p. 22852303.

Bartlett, G. A. and Smith, L., 1971. Mesozoic and Cenozoic history of the Grand Banks of Newfoundland, Canadian J. Earth Sci., v. 8, p. 65-84.

Benson, W. E. and Sheridan, R. E., 1976. In the North Atlantic deep sea drilling (Leg 44), Geotimes, v. 21, p. 23-26.

Bernouilli, D., 1972. North Atlantic and Mediterranean Mesozoic facies: a comparison. In Hollister, C. D., Ewing, J. I., et al., Initial Reports of the Deep Sea Drilling Project, v. 11: Washington (U.S. Government Printing Office), p. 1077.

Boillot, G. and Capdevilla, R., 1977. The Pyrenees: subduction and collision, Earth Planet. Sci. Lett., v. 35, p. 151160.

Boillot, G. and Mougenot, D., 1977. Notice explicative de la carte géologique au $1 / 1.000 .000$ du plateau continental Portugais, Carte Géol. du Portugal, B.R.G.M., C.N.E.X.O.

Bouillot, G., Dupeuble, P. A., and Malod, J., in press. Subduction and tectonics on the continental margin off northern Spain, Mar. Geol.
Dupeuble, P. A., Boillot, G., Lamboy, M., Malod, J., Mauffret, A., and Mougenot, D., 1977. Le passage JurassiqueCretace sur la marge continentale Atlantique de la Péninsule Iberique, Fifth Reunion Ann. Sci. Terre., Rennes, 1977 , p. 210.

Dupeuble, P. A., Réhault, J. P., Auxiètre, J. L., Dunand, J. P., and Pastouret, L., 1976. Résultats de dragages et essai de stratigraphie des bancs de Galice et des montagnes de Porto et de Vigo (marge occidentale ibérique), Mar. Geol., v. 22, p. M37-M49.

Durand-Delga, M., 1973. Les calpionelles du Golfe de Gascogne, témoins de l'ouverture de l'Atlantique Nord, Bull. Soc. Géol. Fr., v. 15, p. 22-24.

Hart, M. B., 1975. The Mid-Cretaceous succession of Orphan knoll (N.W. Atlantic) micropalaeontology and palaeooceanographic implications. Canadian J. Earth Sci., v. 13, p. 1411-1421.

Hart, M. B. and Tarling, D. H., 1974. Cenomanian paleogeography in the North Atlantic and possible mid-cenomanian eustatic movements and their implication, Paleogeogr., Paleoclim., Paleoecol., v. 15, p. 95-108.

Hayes, D. E. and Rabinowitz, P. D., 1975. Mesozoic magnetic lineations and the magnetic quiet zone off NorthWest Africa, Earth Planet. Sci. Lett., v. 28, p. 105-115.

Hays, J. D. and Pitman, W. L., III, 1973. Lithospheric plate motion sea level changes and climatic and ecological consequence, Nature, v. 246, p. 18-22.

Hesse, R., 1975. Turbiditic and non-turbiditic mudstone of Cretaceous flysch sections of the East Alps and other basins, Sedimentology, v. 22, p. 387-416.

Hollister, C. D., Ewing, J. I., et al., 1972. Initial Reports of the Deep Sea Drilling Project, v. 11: Washington (U.S. Government Printing Office).

Jansa, L. F. and Wade, J. A., 1975. Geology of the continental margin off Nova Scotia and New Foundland, Geology of Eastern Canada, Paper 74-30, v. 2.

Lamboy, M., 1976. Géologie marine et sous-marine du plateau continental au NW de l'Espagne. Gènése des glauconies et des phosphorites. Thése d'Etat, Rouen.

Lancelot, Y., Siebold, E., et al., 1975. The Eastern North Atlantic (Leg 41), Geotimes, v. 20, p. 18-21.

Lancelot, Y., Hathaway, J. C., and Hollister, C. D., 1972. Lithology of sediments from the Western North Atlantic, Leg 11. In Hollister, C. D., Ewing, J. I., et al., Initial Reports of the Deep Sea Drilling Project, v. 11: Washington (U.S. Government Printing Office), p. 901-950.

Laughton, A. S., Berggren, W. A., et al., 1972. Initial Reports of the Deep Sea Drilling Project, v. 12: Washington (U.S. Government Printing Office).

Laughton, A. S., Roberts, D. G., and Graves, R., 1975: Bathymetry of the Northeast Atlantic: Mid-Atlantic Ridge to Southwest Europe, Deep-Sea Res., v. 22, p. 791-810.

Leclaire, L., 1974. Late Cretaceous and Cenozoic pelagic deposits. Paleoenvironment and paleo-oceanography of the Central Western Indian Ocean. In Simpson, E. S. W., Schlich, R., et al., Initial Reports of the Deep Sea Drilling Project, v. 25: Washington (U.S. Government Printing Office), p. 481-512.

Montadert, L., Roberts, D. G., et al., 1976. From Brest to Aberdeen: Glomar Challenger sails on Leg 48, Geotimes, v. 21 , p. 19-23.

Montadert, L., Winnock, E., Delteil, J. R., and Grau, G., 1974. Continental margins of Galicia - Portugal and Bay of Biscay. In Burk, C. A. and Drake, C. L. (Eds.), The geology of continental margins: New York (Springer), p. 323-342. 
J. P. RÉHAULT, A. MAUFFRET

Mougenot, D., 1976. Géologie du plateau continental Portugain (antre le Cap Carvoeiro et le Cap de Sines), These $3^{\circ}$ Cycle, Paris.

Mouterde, R., Ruget C., 1975. Esquisse de la paléogéographie du Jurassique inférieur et moyen au Portugal, Bull. Soc. Géol. France, 7, XVII, p. 779-786.

Muselec, P., 1974. Géologie du plateau continental Portugais au Nerd du cap Carvoeiro, These $3^{\circ}$ Cycle, Rennes.

Key, J., 1969. Les grès Albo-Aptiens et la paléogéographie du Crétacé inférieur Portugais, C. R. Acad. Sci. Paris, v. 269, p. $1827-1830$.

, 1972. Recherche géologiques sur le Crétacé inférieur de l'Estramadure Portugaise, Thèse, Toulouse.

Ryan, W. B. F., Sibuet, J. C., et al., 1976. Passive continental margin (Leg 47), Geotimes, v. 21, p. 21-24.

Sibuet, J. C. and Le Pichon, X., 1971. Structure gravimètrique du Golf de Gascogne et le fosse marginal nordespagnol. Histoire structural du Golfed de Gascogne: Paris (Technip), VI-9-1 to VI-9-18.

Tucholke, B., Volt, P., et al., 1975. Leg 43, Geotimes, v. 20, p. $18-21$. van Andel, T. H., 1975. Mesozoic-Cenozoic calcite compensaion depth and the global distribution of calcareous sedimints, Earth Planet. Sci. Lett., v. 26, p. 187-194.

van Houten, L., 1977. Triassic-Liassic deposits of Morocco and eastern North America, Am. Assoc. Petrol. Geol. Bull., p. 79-99.

Wilson, R. C. L., 1975. Atlantic opening and Mesozoic contmental margin basins of Iberia, Earth Planet. Sci. Lett., v. 25 , p. $33-43$.

APPENDIX A

Reader's Guide to the Sedimentologic Chart

In the back pocket of this volume, Chart 2 is a Hole 398D sedimentologic data compilation presented in the form of a set of microfiche cards. The samples examined in the course of this study and presented in Chart 2 are the same individual constituents of the Cretaceous series (from Cores 138 to 56 in Hole 398D) that were studied stratigraphically by Signal (this volume). Signal's stratigraphic range Chart 1 (see back pocket, this volume) and our Chart 2 are presented on the same scale, to facilitate reader use. By comparing these sedimentologic and stratigraphic findings, the user can explore the paleologic and lithologic relationships of these Hauterivian to Cenomanian sediments.

676 
CHART 2 (EXCERPT)

Basal Portion of Site 398 Sedimentologic Chart. (For the complete chart, see microfiche in back pocket, this volume).

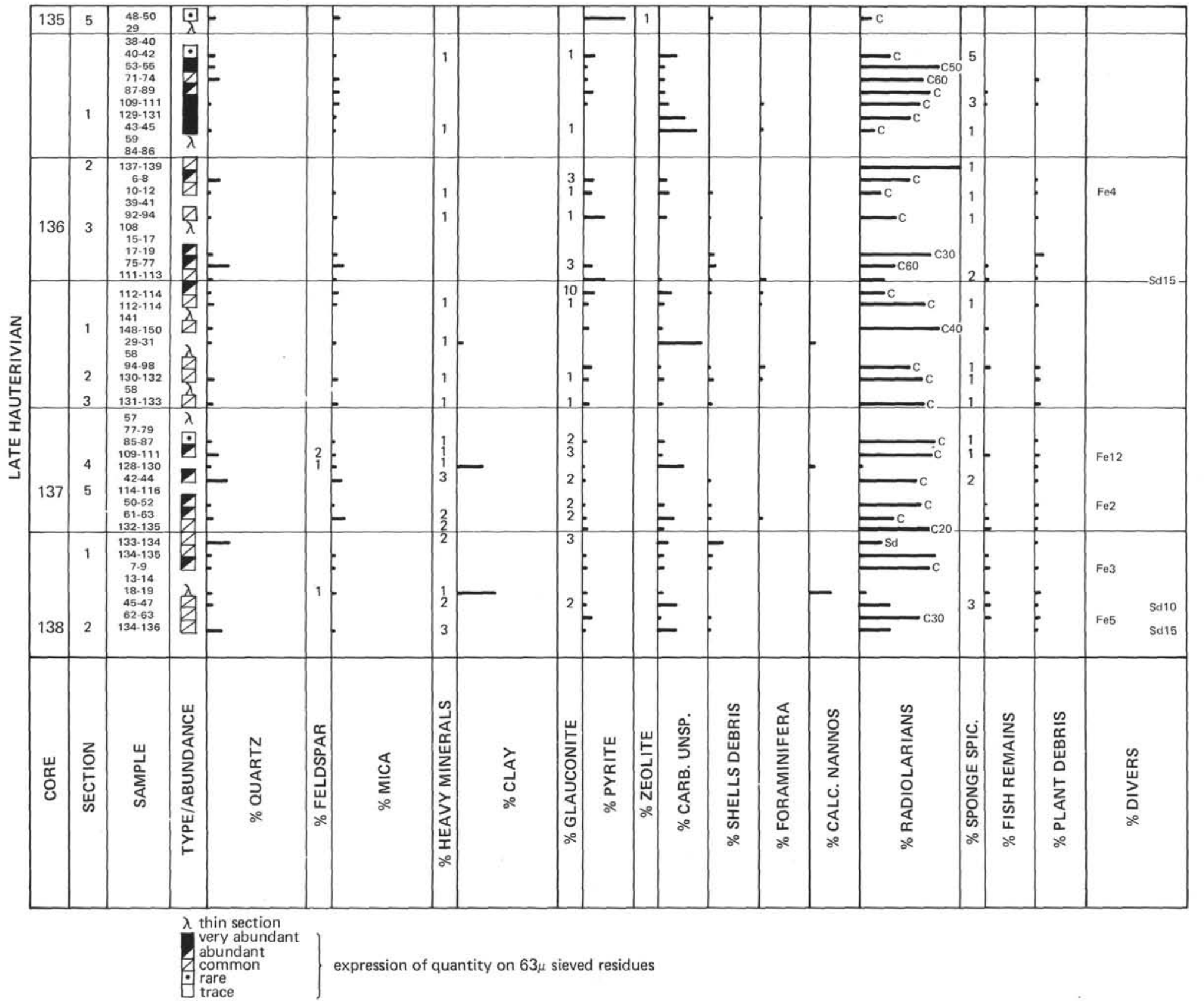




\section{PLATE 1}

Figure 1 Thin-section Sample 398D-132-1, $42-44 \mathrm{~cm}$, early Barremian. Massive nannofossil radiolarian limestones. All radiolarians are totally calcitized and dispersed in the micritic matrix. Pelagic deposit.

Figure 2 Thin-section Sample 398D-132-3, $127 \mathrm{~cm}$, early Barremian. Also nannofossil radiolarian limestones. Radiolarians are concentrated in beds, indicative of reworking by bottom currents.

Figure 3 Thin-section Sample 398D-133-3, 35-37 cm, late Hauterivian. Hemipelagic mudstone with abundant accumulation of plant debris linked to quartz, mica, and reworked radiolarian micritic gravels.

Figure 4 Thin-section Sample 398D-118-2, 72-74 cm, early Gargasian (late Aptian). Silt to sandstone with angular quartz, mica, vegetal debris, and recrystallized radiolarian.

Figure 5 Sample 398D-124-3, 56-72 cm. Breccias of Tithonian pebbles reworked in mudstone.

Figure 6 Thin-section Sample 398D-117-4, 28-130 cm, early Gargasian (late Aptian). Debris flow to grain flow. We observed carbonaceous gravels resedimented in a mudstone matrix with heavy minerals recrystallized and pyritized radiolarians, fish remains, and vegetal debris. 


\section{PLATE 1}
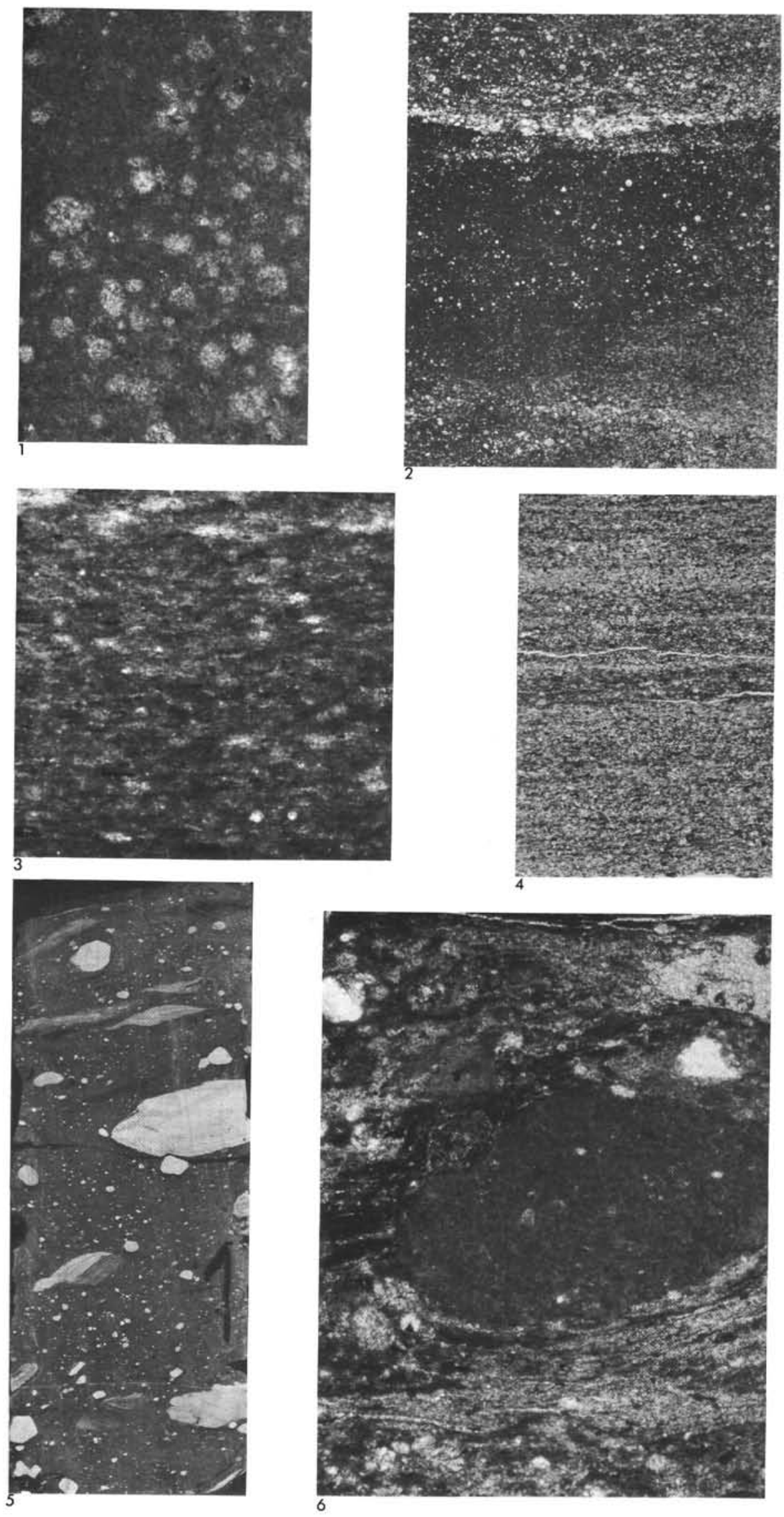


\section{PLATE 2}

Figure 1 Thin-section Sample 398D-123-4, 34-35 cm, Bedoulian (early Aptian). Silt to sandstone with angular quartz, mica, vegetal debris, and recrystallized radiolarians.

Figure 2 Thin-section Sample 398D-101-1, 139-40 cm, early Albian. Radiolarians, sandy mudstone interstratified in dark claystones. Note the accumulation of radiolarians and calcareous gravels, quartz, micas, and vegetal debris.

Figure 3 Thin-section Sample 398D-43-3, $71 \mathrm{~cm}$, Maestrichtian. Microfacies with planktonic foraminifers, some of which are infilled by pyrite.

Figure 4 Sample 398D-41-6, 24-25 cm, late Danian. Azoic facies with quartz.

Figure 5 Sample 398D-40-3, 8-10 cm, early Paleocene. Redeposited facies with accumulation of planktonic foraminifers, calcareous gravels, spicules, quartz, etc.

Figure 6 Sample 398D-38-2, 108-109 cm, middle Paleocene. Redeposited and detrital microfacies with gravels, quartz, micas, radiolarians, and "filaments": lamellibranchs(?). 


\section{PLATE 2}
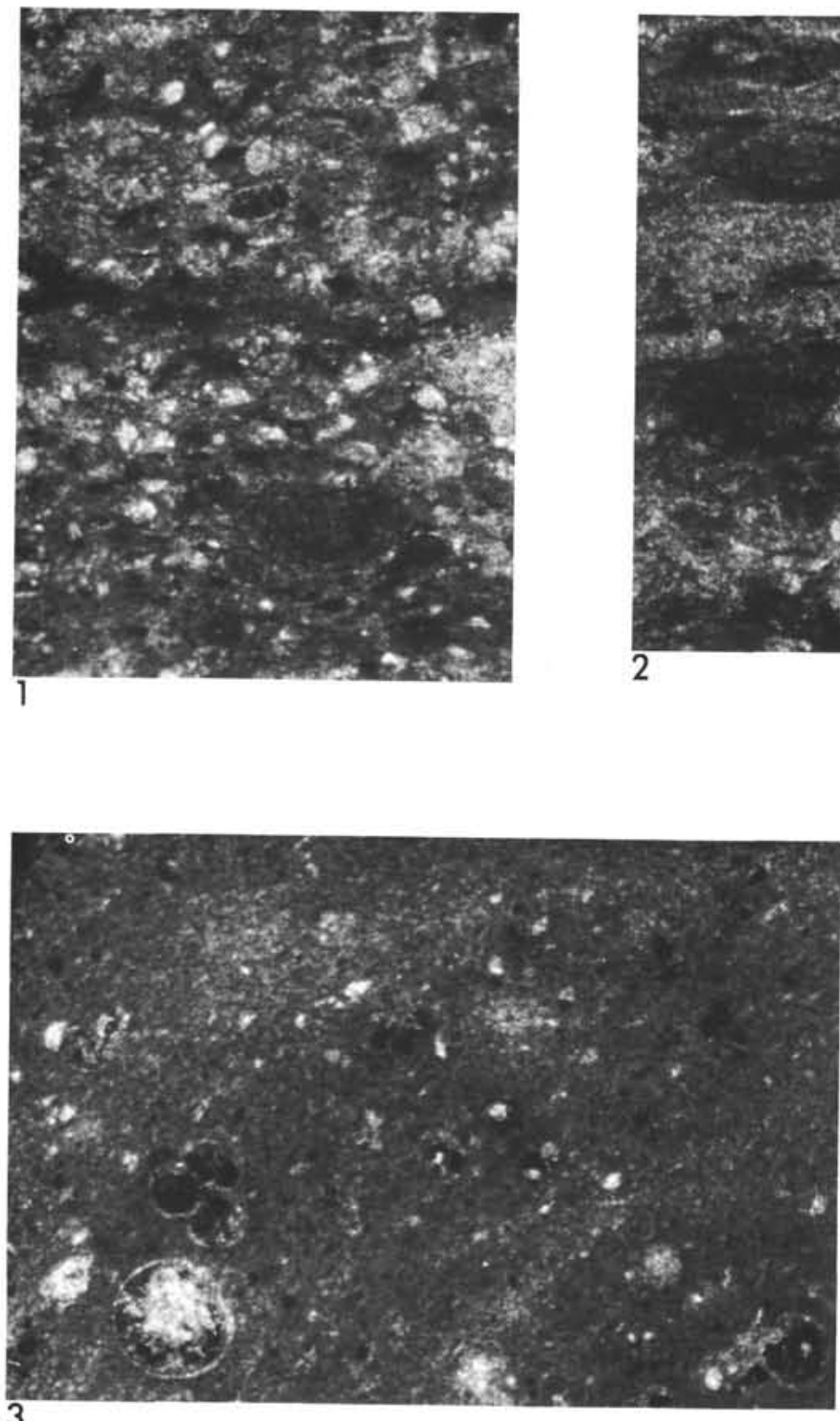

3

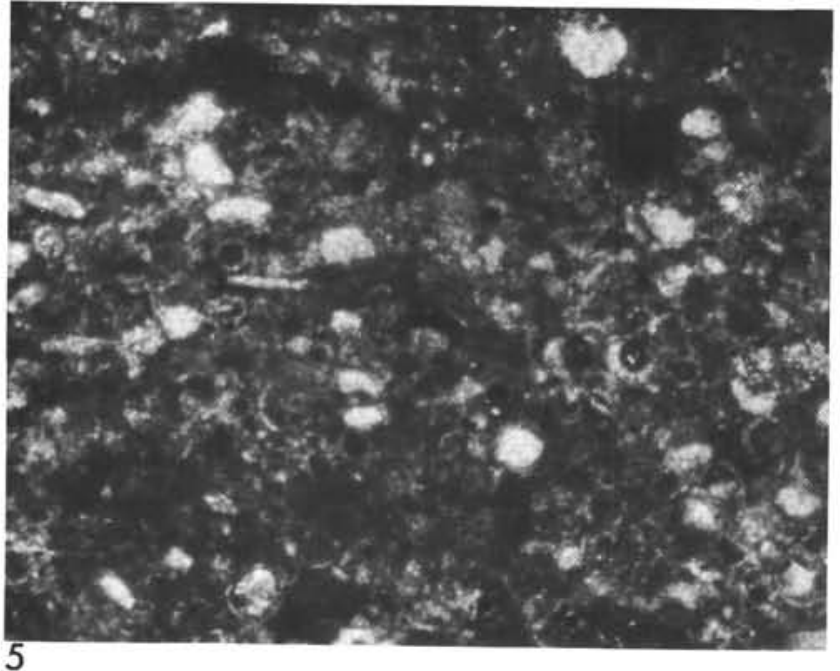

5
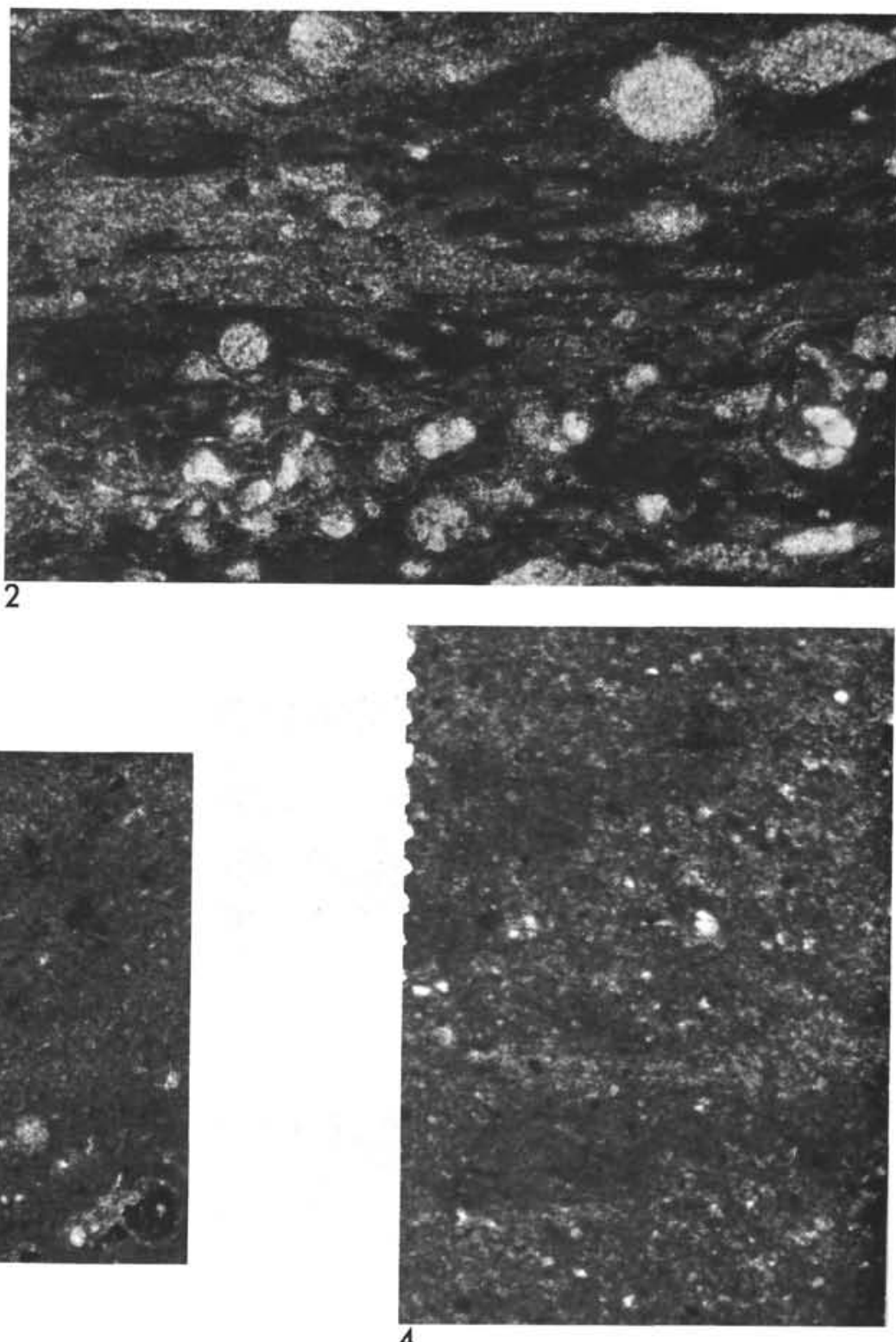

4 